\title{
Photosynthetically stimulated bioerosion in symbiotic sponges: the role of glycerol and oxygen
}

\author{
Michelle Achlatis ${ }^{1,2,3}$ - Rene M. van der Zande Znd $^{2,4}$ Alice E. Webb $^{5}$. \\ Didier M. de Bakker ${ }^{5,6} \cdot$ Lennart J. de Nooijer ${ }^{5}$ Jasper M. de Goeij ${ }^{1,2}$
}

Received: 11 December 2020/Accepted: 3 April 2021/Published online: 29 April 2021

(C) The Author(s) 2021

\begin{abstract}
On coral reefs, some of the most aggressive calcium carbonate eroders are dinoflagellate-hosting sponges of the genus Cliona. Like in other marine taxa, the influence of these symbiotic microorganisms on the metabolism of the host sponge, and thereby on erosion of the surrounding ecosystem, is increasingly acknowledged. Despite elevating $\mathrm{pH}$ (and hence carbonate saturation state), dinoflagellate photosynthesis promotes bioerosion by their hosts. This paradox might be solved by a spatial isolation of photosynthesis from carbonate dissolution, but it remains unknown which mechanism connects the dinoflagellates' photosynthesis with the sponge's bioerosion. Here, we simulate the outcomes of photosynthesis in
\end{abstract}

Topic Editor Simon Davy

Supplementary Information The online version contains supplementary material available at https://doi.org/10.1007/s00338021-02091-0.

Michelle Achlatis

machlatis@calacademy.org

1 Department of Freshwater and Marine Ecology, Institute for Biodiversity and Ecosystem Dynamics, University of Amsterdam, 1090 GE Amsterdam, The Netherlands

2 CARMABI Foundation, Piscaderabaai z/n, P.O. Box 2090, Willemstad, Curaçao

3 Institute for Biodiversity Science \& Sustainability, California Academy of Sciences, San Francisco, CA 94118, USA

4 School of Biological Sciences, The University of Queensland, Brisbane, QLD 4072, Australia

$5 \quad$ NIOZ Royal Netherlands Institute for Sea Research and Utrecht University, 1790 AB Den Burg, The Netherlands

6 Wageningen Marine Research, 1780 AB Den Helder, The Netherlands two separate ways, namely as production of carbon-rich compounds (in this case glycerol) and as an increase in oxygen content. This allows testing their potential to enhance bioerosion rates of sponge holobionts that were preconditioned under variable photosynthetic regimes. We find that glycerol, a commonly shared photosynthate in marine symbioses, stimulates chemical bioerosion rates in the dark of photosynthetically impaired sponges. Chemical bioerosion was all the more limited by availability of sufficient oxygen, while the combination of added glycerol and oxygen boosted chemical bioerosion rates. We argue that under normal physiological conditions, bioerosion is promoted by both organic carbon and oxygen production, and we provide evidence for the storage of photosynthates for night-time use. We further discuss our findings in the context of the current knowledge of the bioerosion mechanism, which we expand by integrating the effects of carbon-rich compounds and oxygen as drivers for bioerosion by Cliona.

Keywords Bioerosion · Cliona - Glycerol - Oxygen · Photosynthesis · Symbiodiniaceae

\section{Introduction}

Symbiotic microorganisms are increasingly recognized as cornerstone components of the metabolism of marine holobionts, thereby impacting their overall ecological functioning. Analogous to 'Russian Matryoshka dolls', the concept of nested ecosystems thus predicts that microorganismal functionality has cascading effects to higher community or ecosystem levels (McFall-Ngai et al. 2013; Kelly et al. 2018; Pita et al. 2018; Dittami et al. 2021). Tropical coral reefs owe their existence to such a ripple 
effect: photosynthesis by endosymbiotic dinoflagellates enables fast calcification rates by scleractinian corals in oligotrophic waters, allowing them to build reefs, which in turn house a diverse array of organisms sustaining an even more diverse food web (Goreau et al. 1979; Stanley 2006; Fisher et al. 2015).

Depending on the characteristics of each of the nested levels, microorganismal functionality can have contrasting effects. When in symbiosis with bioeroding Clionaidae sponges for instance, photosynthesis by endosymbiotic dinoflagellates stimulates some of the fastest rates of calcium carbonate $\left(\mathrm{CaCO}_{3}\right)$ breakdown by invertebrates on coral reefs (reviewed by Schönberg et al. 2017a). This apparent geochemical paradox-the temporal co-occurrence of photosynthesis, which increases $\mathrm{CaCO}_{3}$ saturation due to $\mathrm{CO}_{2}$ uptake, and decalcification, which requires decreased $\mathrm{CaCO}_{3}$ saturation-is hypothesized to be possible due to the spatial separation of the two processes: photosynthesis takes place inside intracellular dinoflagellates found during the day in the upper, sunlit sponge body, whereas bioerosion is active at the interface of sponge and $\mathrm{CaCO}_{3}$ substrate, which is at least several cell membranes and millimetres deeper (Schönberg and Suwa 2007; Achlatis et al. 2019; Webb 2019). In this way, symbiont photosynthesis and host bioerosion not only co-occur, but the former would even stimulate the latter (Achlatis et al. 2019). As a result, erosion by some clionaid species amounts to more than $10 \mathrm{~kg}$ of $\mathrm{CaCO}_{3}$ per $\mathrm{m}^{2}$ sponge surface per year (Schönberg et al. 2017a). With a decrease in net accretion rates due to a strong decline in reefbuilding corals in the past decades, sponge bioerosion threatens to tip the balance towards net erosion on certain reefs (e.g., Nava and Carballo, 2008; Schönberg et al. 2017b). The ability of reefs to maintain positive carbonate balances is fundamental to their already threatened persistence and the crucial ecosystem services they provide (Glynn 1997; Moberg and Folke 1999; Kennedy et al. 2013).

While the physiological mechanisms linking symbiont photosynthesis to coral calcification have been scrutinized for decades (reviewed in Allemand et al. 2011), similar studies are urgently needed in the opportunistic, globally increasing, coral-undermining bioeroding sponges. These sponges already pose significant threats to coral growth worldwide, and their bioerosion rates are expected to increase disproportionately in the coming decades (LópezVictoria and Zea 2005; González-Rivero et al. 2011; Schönberg et al. 2017a). Renewed interest in the bioerosion mechanism of sponges has uncovered a localized $\mathrm{pH}$ reduction that facilitates chemical dissolution at the etching site, likely maintained by actively pumping protons, which are stored within specialized excavating cells in the form of low-pH intracellular vesicles. Together with $\mathrm{CaCO}_{3}$ chips that are mechanically removed by these cells, $\mathrm{Ca}^{2+}$ is thought to be discharged into excurrent canals via pathways of myocyte-like cells that coalesce at the boring pit (Webb et al. 2019). Maintenance of such a $\mathrm{H}^{+} / \mathrm{Ca}^{2+}$ gradient would require a constant supply of energy in oversaturated seawater (Garcia-Pichel 2006). Alongside efficient heterotrophic feeding, symbiont photosynthesis may well supplement this energetic need (Weisz et al. 2010; Fang et al. 2014; Achlatis et al. 2018, 2019), but the underlying mechanisms remain unclear.

Photosynthesis results in a production of high-caloric organic carbon photosynthates and a highly oxygenated microenvironment. Here, we delineate the role of symbiont photosynthesis in sponge bioerosion and the resulting reef dissolution, by artificially simulating these two main photosynthetic outcomes under dark conditions, and testing their independent and concomitant effects. Increased organic carbon availability was simulated in the form of glycerol $\left(\mathrm{C}_{3} \mathrm{H}_{8} \mathrm{O}_{3}\right)$, a low-molecular mass photosynthate that supports several basic metabolic pathways and is translocated by photosymbionts in various marine invertebrate symbioses (Venn et al. 2008), including sponges (Wilkinson 1979; Arillo et al. 1993). The oxygen-rich microenvironment was achieved by supersaturating seawater with $\mathrm{O}_{2}$ (e.g., Colombo-Pallotta et al. 2010; Wijgerde et al. 2012). To account for potential influences of photosynthetic products stored during the day, sponge holobionts that were previously either photosynthetically active or inactive were tested. As an experimental model, we used the abundant Caribbean species Cliona caribbaea Carter, 1882 which is known to erode at higher rates during daytime when photosynthesis of its intracellular symbionts is active (Webb et al. 2017; De Bakker et al. 2018).

\section{Materials and methods}

\section{Sponge collection}

Cliona caribbaea (Porifera: Demospongiae) is one of the most common Caribbean sponges (Loh and Pawlik 2014). It belongs to the Cliona viridis species complex and it hosts intracellular dinoflagellates of the genera Gerakladium and Symbiodinium (formerly Symbiodinium clades G and A, respectively, LaJeunesse et al. 2018) (Zea and Weil 2003; Granados et al. 2008). C. caribbaea individuals in encrusting "beta" morphology (Schönberg et al. 2017b) inhabiting dead Orbicella annularis colonies were sampled by SCUBA (7-12 m water depth) in July 2019 at station "Buoy 0" on the leeward side of the fringing reef of Curaçao in the Southern Caribbean $\left(12.1246^{\circ},-68.9728^{\circ}\right)$. In total, 64 cylindrical cores of $35 \mathrm{~mm}$ in diameter and $15 \mathrm{~mm}$ long were collected from 16 different sponge 
individuals (while tracking the origin of each core) using a pneumatic drill and a hole-saw (Fig. 1a). Each core consisted of an upper disc of sponge-penetrated $\mathrm{CaCO}_{3}$ and an underlying ca. $3 \mathrm{~mm}$ thin disc of non-penetrated $\mathrm{CaCO}_{3}$ (bulk density $=1.15 \pm 0.04 \mathrm{~g} \mathrm{~cm}^{-3}$ and porosity $=34.07 \pm 0.80 \% \quad($ mean $\pm \mathrm{SE})$ of $3 \mathrm{CaCO}_{3}$ pieces from each $O$. annularis colony). All collected cores were left to heal for two weeks while monitored at the collection site at $10 \mathrm{~m}$ depth. Full tissue regeneration was observed well within this period and subsequently the cores were transported to the Caribbean Research and Management of Biodiversity (CARMABI) marine research station, where they were randomly allocated to 8 groups ( $n=8$ per group) (Fig. 1b).

\section{Preconditioning: manipulating photosynthetic activity}

To inhibit daytime photosynthesis, half of the sponges $(n=32)$ were exposed for $2 \mathrm{~d}$ prior to the bioerosion incubations to the herbicide/algaecide DCMU [N'-(3,4dichlorophenyl)-N,N-dimethylurea, also known as diuron] (Fig. 1b). Under the presence of light, DCMU reversibly binds to the D1 protein of photosystem II. This blocks the electron transport along the photosynthetic chain, thereby specifically inhibiting photosynthesis, but without directly affecting the host (Krause and Weis 1991; Watanabe et al. 2006; Achlatis et al. 2019). The replicate sponges $(n=8)$ of each relevant group were distributed over 3 continuously mixed containers that each held $1.4 \mathrm{~L}$ of confined, DCMUenriched seawater. The containers were submerged in a flow-through water bath for temperature regulation, which was placed outdoors and covered with Marine Blue 131 light filters to simulate the light quality and quantity at the collection site (40\% light reduction, Lee Filters, Andover, UK). The water bath was continuously supplied with seawater from $10 \mathrm{~m}$ depth at the nearby reef. Water temperature ranged between $28.4-31.2{ }^{\circ} \mathrm{C}$ and $28.3-28.8^{\circ} \mathrm{C}$ during day and night, respectively (Hobo Pendant loggers, Onset, Bourne, USA). DCMU dissolved in ethanol was added to the containers daily at $1100 \mathrm{~h}$ (final concentration $100 \mu \mathrm{g} \mathrm{L}^{-1}$ as in Achlatis et al. 2019). Previous analyses have shown that the small quantity of ethanol added does not affect the sponges (Achlatis et al. 2019). Everyday at $1500 \mathrm{~h}$ all water was refreshed including a new dose of DCMU. At $2000 \mathrm{~h}$, the sponges were removed from the containers and placed in flow-through non-DCMU water overnight, remaining shaded until the next addition of DCMU. Thus, inhibited sponges did not photosynthesize for $2 \mathrm{~d}$ prior to the bioerosion incubations. The sponges that were not exposed to DCMU (referred to as photosynthetically unaltered) underwent the identical procedure in parallel outdoor containers that were filled with ambient DCMU-free seawater and placed inside the same water bath. All sponges were observed to be actively pumping, irrespective of the addition or absence of DCMU. During the experiment, sunrise was at $0622 \mathrm{~h}$ and sunset at $1901 \mathrm{~h}$, while average PAR light at solar noon (1242 h) was $782 \pm 102 \mu \mathrm{mol}$ quanta $\mathrm{m}^{-2} \mathrm{~s}^{-1}$ (mean $\pm \mathrm{SE}$, Odyssey light loggers, Dataflow Systems, Christchurch, New Zealand).

The impact of DCMU on photosynthetic $\mathrm{CO}_{2}$ fixation was quantified during the preconditioning phase (2nd afternoon) using oxygen evolution measurements on a subset of photosynthetically unaltered $(n=8)$ and photosynthetically inhibited sponges $(n=8)$. To measure maximum net photosynthesis of the symbionts, the sponges were subjected to 25 min of natural light with an intensity of $670 \pm 57 \mu \mathrm{mol}$ quanta $\mathrm{m}^{-2} \mathrm{~s}^{-1}$ (mean $\pm \mathrm{SE}$ ), with oxygen levels logged every $15 \mathrm{~s}$ using Presens OXY-4 optical probes (Presens GMBH, Regensburg, Germany). Oxygen levels were measured in air-tight, temperature- a

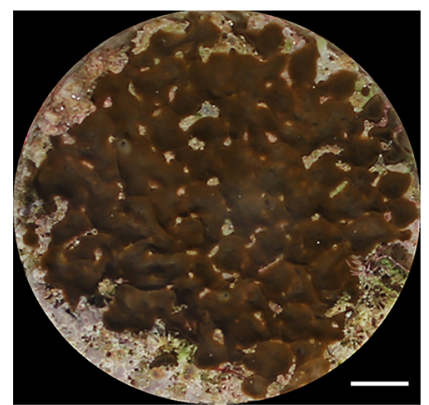

b

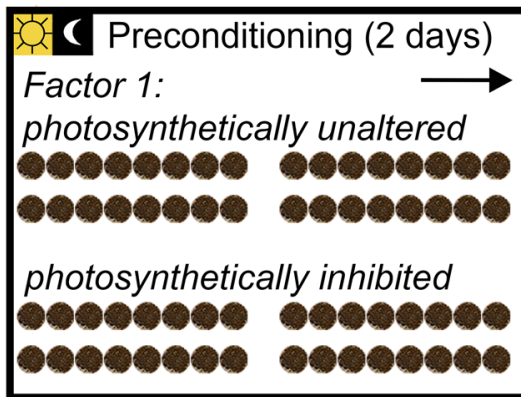

C

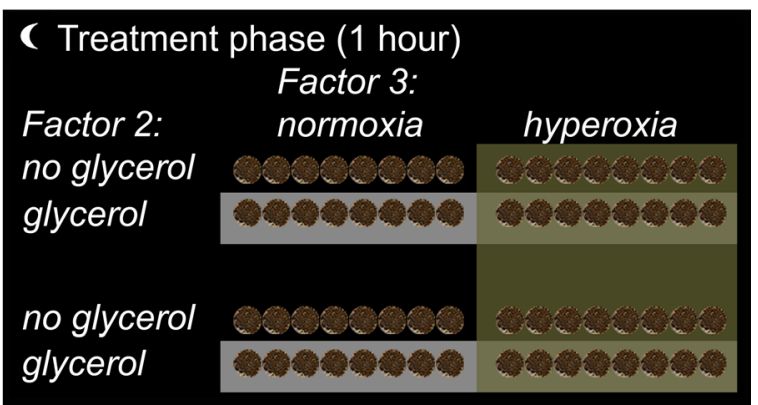

Fig. 1 a Top view of a Cliona caribbaea core used in the experiment. Scale bar $=5 \mathrm{~mm}$. b Experimental design. During the preconditioning phase ( $2 \mathrm{~d}$ under a natural light cycle, in white), the photosynthetic activity of half of the sponges was manipulated using DCMU (factor 1$)$. c In the subsequent treatment phase $(1 \mathrm{~h}$ on the second night), the bioerosion rates of the sponges were measured in the dark (in black) under an orthogonal supplementation of glycerol (factor 2) and oxygen (factor 3). In addition, the bioerosion rates of four photosynthetically unaltered sponges (that had not been exposed to glycerol or oxygen) were measured in the light on the following day (not shown in figure) 
controlled incubation chambers (placed inside the outdoor water bath described above) containing $1.6 \mathrm{~L}$ filtered seawater $(25 \mu \mathrm{m})$ without trapped air bubbles and continuously stirred. Each sponge incubation was preceded by a background non-sponge seawater-only incubation that also lasted $25 \mathrm{~min}$ to determine microbial oxygen changes in the water column, which were then used to correct the final oxygen fluxes that were calculated from the sponge-containing incubations.

\section{Treatment phase: chemical bioerosion incubations}

At the end of the preconditioning phase (2nd night), the sponges were returned to flow-through seawater (DCMUfree) for $1 \mathrm{~h}$ before their chemical bioerosion rates were determined. To isolate the impacts of glycerol and oxygen production, bioerosion rates were measured in the dark under four different treatments, each applied on both photosynthetically unaltered and photosynthetically inhibited sponges (Fig. 1c):

(1) Control treatment [no glycerol, normoxia, i.e., normal oxygen level]

(2) Glycerol treatment [glycerol, normoxia]

(3) Oxygen supersaturation treatment [no glycerol, hyperoxia]

(4) Combined glycerol and oxygen supersaturation treatment [glycerol, hyperoxia]

This design resulted in 8 groups of sponges $(n=8$ per group). All bioerosion incubations lasted $1 \mathrm{~h}$ in the dark in individual chambers containing one sponge core and $700 \mathrm{~mL}$ of continuously stirred treatment water (no DCMU added, seawater chemistry summarized in Supplementary Table S1). This water was filtered over $25 \mu \mathrm{m}$ and thus contained bacterio- and phytoplankton and dissolved organic matter (DOM) for heterotrophic feeding. Glycerol (AR, Fisher Chemical, Waltham, USA, pH = 5) was preadded to the incubation chambers (1\% final concentration based on Colombo-Pallotta et al. 2010 and Holcomb et al. 2014), causing alkalinity to decrease by $17.31 \pm 2.59$ $\mu$ mol kg ${ }^{-1}$ (mean $\pm \mathrm{SE}$, measured as described below). Hyperoxia was continuously maintained at $160 \%$ saturation (10.31 compared to $6.44 \mathrm{mg} \mathrm{O}_{2} \mathrm{~L}^{-1}$ in control treatments) throughout the incubations by adding pure oxygen regulated to $<1$ bar pressure (Haas et al. 2014). Hyperoxia occurs commonly during dinoflagellate photosynthesis inside marine invertebrates and at a higher level than implemented here (Shick 1990; Kuhl et al. 1995). Additional daytime incubations measuring bioerosion rates of a subset of photosynthetically unaltered sponges solely of the control treatment ( $n=4$, no glycerol, normoxia) were performed as a reference on the day following the nighttime incubations. Seawater oxygen saturation, temperature and $\mathrm{pH}$ were monitored throughout each incubation, while open oscula on all sponge core surfaces were indicative of active pumping. Background non-sponge seawater only incubations were used to determine changes in water chemistry over time ( $n=3$ per treatment). Water samples $(250 \mathrm{~mL})$ taken at the beginning (from each individual treatment) and end of the sponge and background incubations were immediately analysed to determine changes in total alkalinity $\left(\mathrm{A}_{\mathrm{T}}\right)$, which were later adjusted for nutrient changes (in $\mu \mathrm{mol} \mathrm{L}{ }^{-1}$ ) (Eq. 1). The background-corrected sponge values were then used to calculate the chemically eroded $\mathrm{CaCO}_{3}$ (Eq. 2) (Zundelevich et al. 2007; Gazeau et al. 2015).

$$
\begin{aligned}
& \Delta \mathrm{A}_{\mathrm{T}\left(\mathrm{CaCO}_{3}\right)}=\left[\Delta \mathrm{A}_{\mathrm{T}(\mathrm{inc})} \times \mathrm{d}_{\mathrm{SW}}\right]+\Delta \mathrm{PO}_{4}-\Delta \mathrm{NH}_{4} \\
& +\Delta\left(\mathrm{NO}_{3}+\mathrm{NO}_{2}\right) \\
& \mathrm{M}_{\mathrm{CaCO}_{3}}=\frac{1}{2} \Delta \mathrm{A}_{\mathrm{T}\left(\mathrm{CaCO}_{3}\right)} \times \mathrm{MM}_{\mathrm{CaCO}_{3}} \times \mathrm{V}_{\mathrm{SW}} \times 10^{-3}
\end{aligned}
$$

where $\Delta \mathrm{A}_{\mathrm{T}\left(\mathrm{CaCO}_{3}\right)}$ is the change in alkalinity ( $\mu \mathrm{mol} \mathrm{L}^{-1}$ ) due to $\mathrm{CaCO}_{3}$ dissolution, $\Delta \mathrm{A}_{\mathrm{T}(\mathrm{inc})}$ is the alkalinity change ( $\mu$ mol $\mathrm{kg}^{-1}$ ) during the incubation, $\mathrm{d}_{\mathrm{sw}}$ is the seawater density (1.022 kg L$\left.{ }^{-1}\right), \mathrm{M}_{\mathrm{CaCO}_{3}}$ is the mass of the dissolved $\mathrm{CaCO}_{3}$ (converted to $\mathrm{mg}$ due to the $10^{-3}$ factor), $\left.\Delta \mathrm{A}_{\mathrm{T}\left(\mathrm{CaCO}_{3}\right)}\right)$ is divided by 2 to match the molar value of dissolved $\mathrm{CaCO}_{3}, \mathrm{MM}_{\mathrm{CaCO}}$ is the molar mass of $\mathrm{CaCO}_{3}$ $\left(100 \mathrm{~g} \mathrm{~mol}^{-1}\right)$, and $\mathrm{V}_{\mathrm{sw}}$ is the incubation volume $(\mathrm{L})$. Chemical bioerosion was then expressed as $\mathrm{mg}$ dissolved $\mathrm{CaCO}_{3} \mathrm{~cm}^{-2}$ sponge tissue $\mathrm{h}^{-1}$. Mechanical bioerosion rates were not assessed here, and chemical rates are only a proxy for the total bioerosion capacity of the sponges. Upper surface areas (in $\mathrm{cm}^{2}$ ) of the sponges were quantified from standardized photographs using ImageJ 1.52p in Fiji platform (Schindelin et al. 2012) with the aid of colour thresholding to selectively measure the live sponge surface without any potentially interspaced $\mathrm{CaCO}_{3}$ (Fig. 1a).

$\mathrm{A}_{\mathrm{T}(\mathrm{inc})}$ was measured with a precision of at least $\pm 0.7 \mu \mathrm{mol} \mathrm{kg}{ }^{-1}$ using an automated spectrophotometric alkalinity system (Liu et al. 2015) following a protocol modified from Breland and Byrne (1993) and Yao and Byrne (1998). Certified reference material was used as a standard (Dickson's CRM, University of California, San Diego, USA). Filtered nutrient samples $(0.2 \mu \mathrm{m}$ syringe filters, Acrodisc, Pall, Port Washington, USA) were frozen $\left(-20{ }^{\circ} \mathrm{C}\right)$ and later analysed for $\left[\mathrm{PO}_{4}{ }^{3-}\right],\left[\mathrm{NH}_{4}{ }^{+}\right]$, $\left[\mathrm{NO}_{3}{ }^{-}+\mathrm{NO}_{2}{ }^{-}\right]$and $\left[\mathrm{NO}_{2}{ }^{-}\right]$(in $\left.\mu \mathrm{mol} \mathrm{L}{ }^{-1}\right)$ on a QuAAtro continuous flow analyzer (SEAL Analytical, GmbH, Norderstedt, Germany) according to the GO-SHIP guidelines (Hydes et al. 2010) at the Royal Netherlands Institute for Sea Research (NIOZ), Texel, the Netherlands.

Night-time respiration of the sponges was also measured at night in the dark using the same setup described above for the daytime $\mathrm{O}_{2}$ assay, but without addition of DCMU. 
For the control and glycerol treatments ( $1 \%$ glycerol as described above), oxygen depletion was logged continuously during $30 \mathrm{~min}$. Respiration was not quantified in the hyperoxia treatments due to the confounding effect of continuous $\mathrm{O}_{2}$ addition.

\section{Statistical analysis}

Preliminary analysis showed no significant effect of the sampling origin of each core or the distribution of the cores across the DCMU-preconditioning containers (nested within the experimental conditions) for any of the variables; therefore, data were pooled according to standard methods (Underwood 1997). Chemical bioerosion rates were analysed following an orthogonal ANOVA model $(2 \times 2 \times 2$ matrix $)$, the factors being photosynthetic capacity (unaltered/ inhibited), glycerol (not supplemented/ supplemented) and oxygen (normoxia/ hyperoxia) ( $n=8$ sponge cores per cell of the design, Fig. 1b, c). Oxygen flux variables were analysed using one- or two-factor ANOVA (detailed in Supplementary Table S2). The assumptions of normality (Shapiro-Wilk test) and homogeneity of variances (Levene's test) were respected. Significance was assessed at the 0.05 level using the software Statistica v.13 (StatSoft, Tulsa, USA). Means and standard errors of means are reported throughout the results (mean $\pm \mathrm{SE}$ ).

\section{Results}

\section{Photosynthesis and respiration}

DCMU effectively blocked photosynthesis during the preconditioning and resulted in net oxygen consumption by sponges (corrected for seawater controls) under light conditions, in contrast to net production in photosynthetically unaltered sponges (ANOVA, $\mathrm{F}_{(1,14)}=47.70, p<0.0001$, Supplementary Table S2, Fig. 2). DCMU preconditioning did not affect the night-time respiration rates (Fig. 2). Regardless of their daytime photosynthetic activity, nighttime respiration of sponges was slightly, but not significantly stimulated by the addition of glycerol (net consumption rate of $3.18 \pm 0.27$ (photosynthetically unaltered) and $2.76 \pm 0.28$ (inhibited) $\mu \mathrm{mol} \mathrm{O} \mathrm{cm}^{-2} \mathrm{~h}^{-1}$, Supplementary Table S2, not shown in Fig. 2) in comparison to the non-glycerol treated individuals shown in Fig. 2.

\section{Chemical bioerosion rates}

During the day, control sponges with unaltered photosynthesis chemically eroded $\mathrm{CaCO}_{3}$ at a rate of

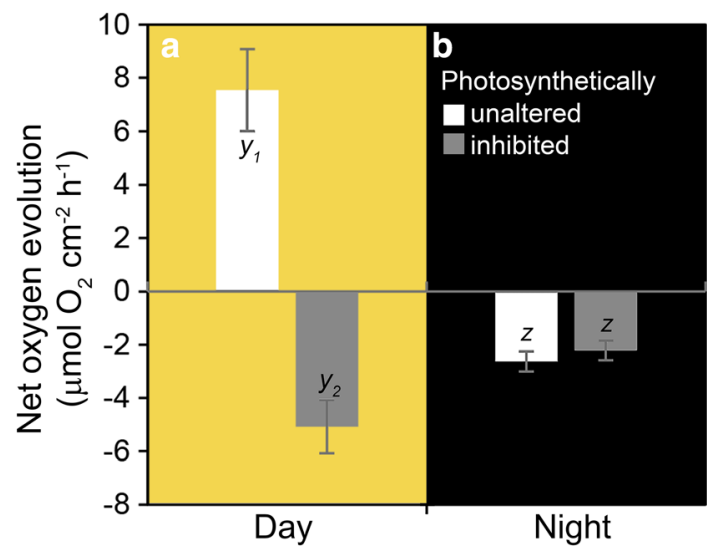

Fig. 2 Net oxygen evolution rates of the bioeroding sponge holobiont Cliona caribbaea a during the day (net photosynthesis, in yellow) and b at night (dark respiration, in black). Rates of photosynthetically unaltered or inhibited (using DCMU) sponge individuals are shown, corrected for seawater control treatments. Oxygen fluxes presented are all in the absence of glycerol or oxygen supplementation. Letters inside bars indicate statistical significance of separate one-way ANOVAs for net photosynthesis (in a) and for dark respiration (in b) respectively (mean $\pm \mathrm{SE}, n=8$ )

$0.033 \pm 0.002 \mathrm{mg} \mathrm{cm}^{-2} \mathrm{~h}^{-1}$. During the night, the chemical bioerosion rate of the same sponges was approximately halved to $0.017 \pm 0.003 \mathrm{mg} \mathrm{cm}^{-2} \mathrm{~h}^{-1}$ (Fig. 3a).

Night-time chemical bioerosion rates were overall significantly higher in the sponges that had not been preconditioned with DCMU and had thus remained photosynthetically active during the preceding days (3factorial ANOVA, main effect, $\mathrm{F}_{(1,56)}=13.29, p<0.001$, Supplementary Table S2, Fig. 3). Under normoxia and in the absence of glycerol, the loss of daytime photosynthesis translated to a $38 \%$ decrease in night-time bioerosion rates (Fig. 3a vs. b, left bars). The individual glycerol and oxygen treatments slightly mitigated that decrease to 33 and $27 \%$, respectively (Fig. 3a vs. b, middle two bars). When glycerol and oxygen additions were combined, the largest decrease in night-time chemical bioerosion rates was found $(>50 \%)$ in photosynthetically inhibited sponges compared to unaltered sponges (Fig. 3a vs. b, right bars).

Regardless of daytime photosynthetic activity, the addition of glycerol stimulated bioerosion rates across all comparisons (main effect, $\mathrm{F}_{(1,56)}=8.07, p=0.006$, Supplementary Table S2, Fig. 3). Under normoxia, this stimulation amounted to an approximately 50\% increase in bioerosion, regardless of the preconditioning (Fig. 3a, b, 1st vs. 2nd bar). Under hyperoxia, the glycerol-mediated stimulation ranged from a negligible increase of $13 \%$ in bioerosion in the photosynthetically inhibited sponges (Fig. 3b, 3rd vs. 4th bar), to an $88 \%$ increase in the photosynthetically unaltered sponges (Fig. 3a, 3rd vs. 4th bar). 


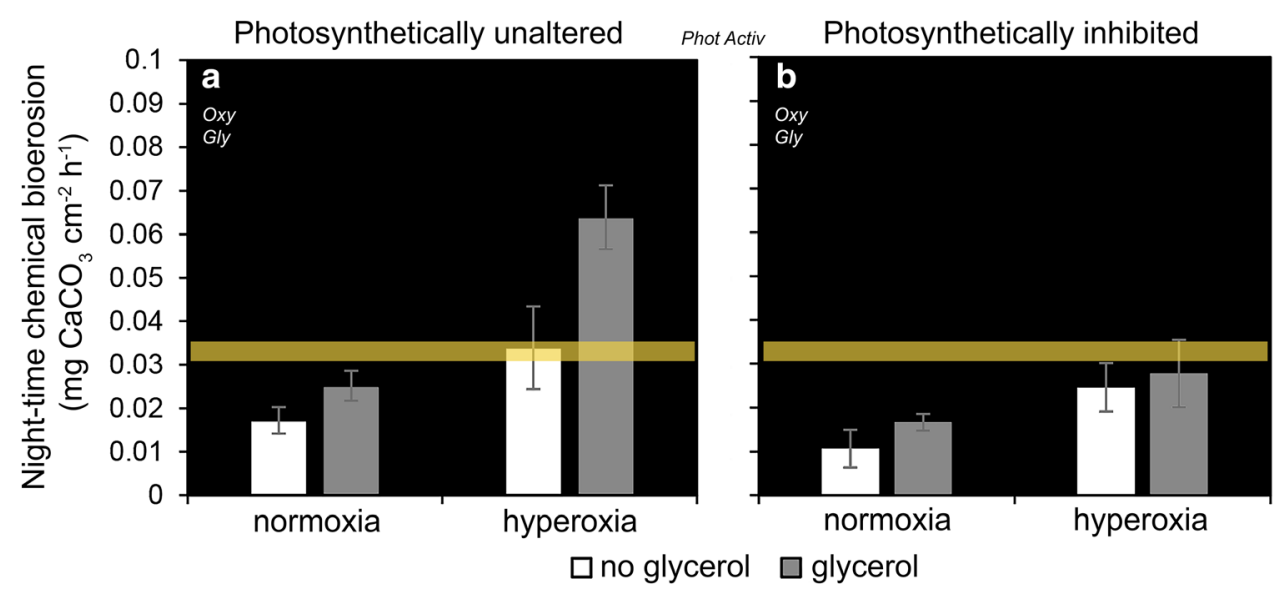

Fig. 3 Net chemical bioerosion rates of the sponge Cliona caribbaea measured at night (black background) under independent and concurrent glycerol and oxygen addition (mean $\pm \mathrm{SE}, n=8$ per group). The photosynthetic activity of the sponges was a unaltered or b inhibited using DCMU during the two days preceding the glycerol and oxygen treatments. All three factors independently affected the bioerosion rates [3-way factorial ANOVA, significant main effects

The hyperoxia treatment showed an even stronger stimulation effect on chemical bioerosion rates than the glycerol treatment (main effect, $\mathrm{F}_{(1,56)}=23.52, p<0.001$, Supplementary Table S2, Fig. 3). In the absence of glycerol, hyperoxia approximately doubled the bioerosion rates of all sponges compared to normoxia (Fig. 3a, b, 1st vs. 3rd bar). When combined with glycerol addition, hyperoxia almost tripled the bioerosion rates of sponges that had been photosynthetically active during the preceding days (Fig. 3a, 2nd vs. 4th bar). For the sponges that had been photosynthetically inhibited but were given glycerol, hyperoxia increased their bioerosion rates by $66 \%$ compared to normoxia (Fig. 3b, 2nd vs. 4th bar).

\section{Discussion}

Photosymbiotic bioeroding sponges are aggressive excavators of $\mathrm{CaCO}_{3}$ on coral reefs and are fuelled by primary productivity of their resident dinoflagellates. By experimentally simulating photosynthesis, we infer that both carbon-rich photosynthates as well as oxygen production by the photosymbionts have a crucial role in driving bioerosion. We thus show how symbiotic microorganisms may influence $\mathrm{CaCO}_{3}$ budgets in nested ecosystems.

\section{The importance of symbiont photosynthesis for sponge bioerosion}

Daytime chemical bioerosion rates of the sponge $C$. caribbaea were higher than night-time rates, as previously reported for this species (Webb et al. 2017; De Bakker indicated by the designations Phot Activ, Oxy and Gly for photosynthetic activity (unaltered vs. inhibited), oxygen saturation (normoxia vs. hyperoxia) and glycerol (no glycerol vs. glycerol addition), respectively]. Daytime bioerosion rates of photosynthetically unaltered, control (no glycerol or oxygen addition) sponges are shown in yellow as a comparative baseline (mean \pm SE range, $n=4$ )

et al. 2018) and other species of the same genus (C. orientalis, Fang et al. 2016; C. aprica, De Bakker et al. 2018 but see Zundelevich et al. 2007; Achlatis et al. 2019). Regardless of the glycerol and oxygen treatments, the inhibition of daytime photosynthesis using DCMU resulted in decreased night-time bioerosion rates. This suggests that when natural photosynthetic activity is unaltered, sugars and other photosynthates produced during daytime photosynthesis are also used to promote night-time bioerosion (Achlatis et al. 2019). These photosynthates are possibly stored in the form of starch or triacylglycerols in the dinoflagellate symbiont cells (Crossland et al. 1980; Kyung and Fritz 2002; Grant et al. 2006), and as glycogen or other mobilizable compounds in the sponge host cells (BouryEsnault 1977; Pomponi 1979). Glycogen granules are abundant in the cytoplasm of sponge excavating cells (Pomponi 1979). In contrast to the photosynthates, oxygen generated during the day is unlikely to be stored until usage during night. This most likely caused the larger effect of experimental oxygen addition on night bioerosion in comparison with the addition of glycerol (i.e., in the presence of already stored photosynthates).

Direct effects of DCMU preconditioning on host physiology that could, in turn, affect sponge bioerosion rates cannot be excluded, but they were not observed (e.g., respiration rates were unaffected) and not expected given the specificity of the herbicide (Negri et al. 2005; Watanabe et al. 2006; Cantin et al. 2007). 


\section{Experimental addition of glycerol and oxygen in the dark}

Across treatments, glycerol accelerated night-time chemical bioerosion by the sponge $C$. caribbaea. ATP generated by glycolysis of glycerol may stimulate bioerosion, and in the sponges that had been photosynthetically active, this apparent enhancement was even higher when oxygen was plentiful. On the other hand, sponges that had been photosynthetically inhibited and thus deprived of photosynthates for their metabolic demands may have readily consumed the added glycerol, or invested it into gluconeogenesis to sustain their basic metabolic needs, thereby retaining relatively less energy for bioerosion. This could have contributed to the lower stimulation of bioerosion due to glycerol compared to the photosynthetically unaltered sponges, at least during the short period of glycerol addition in our experiment. Photosymbiotic sponges are not known to adjust their pumping rates to readily compensate for the loss of autotrophic carbon sources through increased heterotrophic feeding (Fang et al. 2014, 2017; Achlatis et al. 2017; Pineda et al. 2017). Thus, the photosynthetically-inhibited sponges might have been in metabolic need during the DCMU preconditioning and prior to the glycerol addition. Our results also suggest that the addition of glycerol, even at high concentrations, does not supply the full energetic need that is normally derived from diverse photosynthates. We supplied glycerol at a relatively high concentration (see Holcomb et al. 2014 for a comparison of concentrations in corals), and thus we do not expect that this quantity was limiting compared to normal photosynthate production during the day. Instead, we argue that the quality of the supplied photosynthate might have been inferior compared to the range of beneficial compounds (e.g., glucose and other sugars, amino acids, lipids) produced under natural photosynthesis (Berg et al. 2006; Venn et al. 2008). It is also important to note that, even though the addition of glycerol at the start of the incubation lowered the alkalinity and thus the saturation state of aragonite (Supplementary Table S1), the decreased saturation did not correspond to higher bioerosion across the treatments and is thus unlikely to have significantly influenced the observed bioerosion rates.

Oxygen further accelerated night-time chemical bioerosion across the treatments. In the sponges that had been photosynthetically inhibited, hyperoxia lead to bioerosion rates that were almost similar to daytime rates of photosynthetically unaltered sponges. In the glycerol-supplemented, photosynthetically unaltered sponges, daytime rates were surpassed when oxygen was added in the night. The surpassing of daytime bioerosion rates in the night under the high caloric and hyperoxic conditions indicates that our glycerol addition was high compared to normal photosynthate production, and that daytime bioerosion is limited by the rate of normal photosynthate production. Taken together, our results suggest that both photosynthate and oxygen availability are crucial for daytime bioerosion, and that oxygen limitation is the primary factor responsible for comparatively low night-time bioerosion rates under natural conditions. Pumping activity is shown as an important driver of the oxygenation of sponges (Hoffmann et al. 2008; Lavy et al. 2016), and therefore, the inner body of clionaid sponges may be less well oxygenated at night, when their pumping rates decrease and their oscula contract (Strehlow et al. 2016 and references therein). Under decreased pumping, it is plausible that any $\mathrm{CO}_{2}$ accumulated due to night-time respiration could increase acidity and stimulate night-time bioerosion purely due to the resulting chemical microenvironment at the etching site. However, our results suggest that the experimental addition of oxygen stimulates bioerosion more strongly through metabolic activation of the sponge etching cells.

Chemical boring facilitates the mechanical removal of $\mathrm{CaCO}_{3}$ chips by etching cells, and this process would likely also benefit directly from glycerol and oxygen addition. Nevertheless, potential stimulation of mechanical bioerosion and thus the cumulative stimulation of total bioerosion rates by our treatments remain to be determined.

\section{Natural role of glycerol and oxygen in bioerosion}

Little is known about the cellular physiology of the spongedinoflagellate symbiosis and the decalcification mechanism in sponges, particularly in comparison with the coral symbiosis and calcification literature (Schönberg 2008; Allemand et al. 2011; Davy et al. 2012). In the final paragraphs, we integrate our findings with those of recent sponge bioerosion studies, and with testable hypotheses, synthesizing an updated model of sponge bioerosion (Fig. 4) and highlighting current knowledge gaps. While enhanced in photosymbiotic species, the physiological mechanisms that we propose can advance understanding of bioerosion in non-photosymbiotic sponges as well (where high-caloric and oxygen-rich microenvironments are supplied by enhanced filter and suspension feeding), or in other bioeroding invertebrates.

Our glycerol addition simulates the natural production of photosynthates by symbiotic dinoflagellates inside sponges. These dinoflagellates are found inside specialized sponge cells that resemble archaeocytes (Zea and Weil 2003) (Fig. 4a, b). Dinoflagellate photosynthesis generates, amongst others, triose dihydroxyacetone phosphate, which is converted to glycerol via the glycerol-phosphate dehydrogenase enzyme (Ben-Amotz et al. 1982; SuescúnBolívar et al. 2012). We suggest that glycerol is then either consumed by the dinoflagellates, or translocated to sponge 


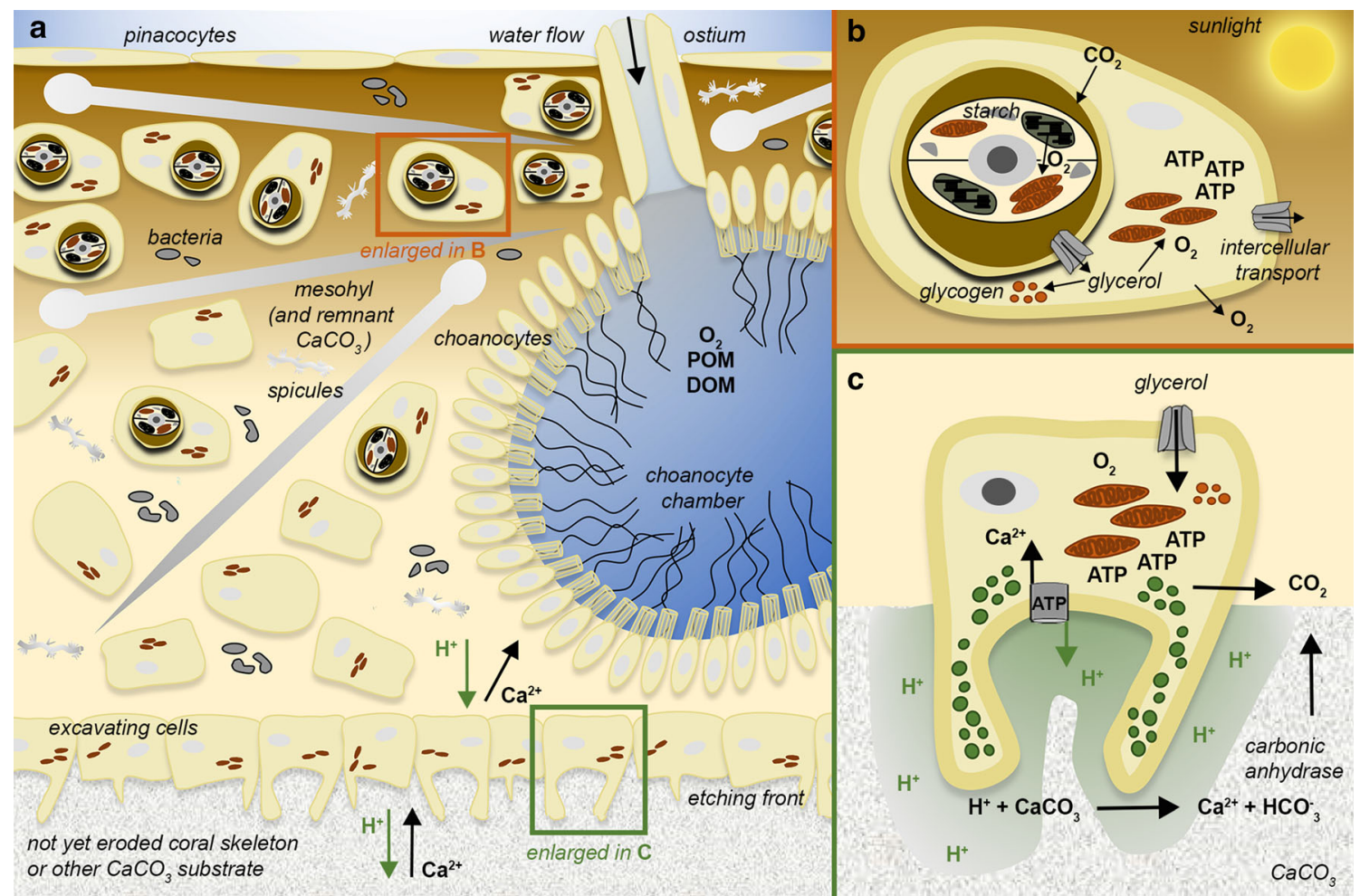

Fig. 4 Conceptual schematic of a photosymbiotic bioeroding sponge during active photosynthesis. a Symbiotic dinoflagellates (brown circles, approx. $10 \mu \mathrm{m}$ in diameter) are hosted intracellularly in archaeocyte-like cells of the upper, sunlit mesohyl of the sponge. (At night, these cells move deeper, away from the outer pinacocyte cell layer). Feeding chambers consist predominantly of flagellated choanocytes that pump water and retain resources (e.g., oxygen, nutrients), which are then transferred to other cells in the mesohyl of the holobiont. The sponge has an endoskeleton made of siliceous spicules (elongated tylostyles and spiny spirasters), but it remains intertwined in the eroded $\mathrm{CaCO}_{3}$ which offers additional support. Excavating cells are mostly concentrated at the etching front at the interface with $\mathrm{CaCO}_{3}$ that has not been eroded yet (distance to sponge

cells possibly through a transmembrane channel that permits osmolyte passage (Fig. $4 \mathrm{~b}, \mathrm{c}$ ), similar to the aquaporins found in a dinoflagellate-hosting freshwater sponge (Mueller and Grachev 2009) or in scleractinian corals (Leggat et al. 2007).

Under natural conditions, once glycerol is translocated from the dinoflagellates to the sponge cells, it can be stored or metabolized together with other photosynthates in the upper sponge body, or transported closer to the excavating cells (Fig. 4b). As our results suggest, the transported glycerol stimulates the metabolism of these cells and, in turn, the bioerosion rates. We hypothesize that such photosynthate transportation towards the excavating cells might be facilitated at night, given that the archaeocyte-like cells that host dinoflagellates are known to migrate deeper into the sponge body in the absence of light (Schönberg and Suwa 2007; Webb 2019). Oxidation of photosynthates is expected to be enhanced by photosynthesis during the surface not to scale with cell sizes). Extensions of their cell membranes named pseudopodia actively participate in chemical and mechanical erosion. b Part of the oxygen produced in dinoflagellate chloroplasts (khaki organelles) and the photosynthates (such as glycerol) are transferred to the hosting sponge cell, where they are either used in mitochondrial oxidation (red organelles), stored, or further transferred to other sponge cells. c Excavating cells consume ATP and use the $\mathrm{H}^{+}$gradients generated by mitochondrial respiration to release protons to the underlying $\mathrm{CaCO}_{3}$, either through $\mathrm{Ca}^{2+}$. ATPases or $\mathrm{H}^{+}$-rich vesicles (green dots) that accumulate in their pseudopodia. The enzyme carbonic anhydrase accelerates the conversion of released bicarbonate to $\mathrm{CO}_{2}$, which may then, alongside released $\mathrm{Ca}^{2+}$, be partly absorbed by dinoflagellate photobiology

day, since $\mathrm{O}_{2}$ (being non-ionic) diffuses across lipid membranes out of the dinoflagellate cells and dissolves in the seawater that is transported via the canals of the sponge throughout the body (Fig. 4a, b). Photosynthate oxidation further generates a mitochondrial proton gradient and ATP (Fig. 4c). Both protons and ATP are necessary to maintain the proton-calcium pathway that has been proposed to supply the pseudopodia of excavating cells with protonfilled vesicles used to dissolve $\mathrm{CaCO}_{3}$ (Fig. 4c), and to enable removal of the generated $\mathrm{Ca}^{2+}$ from the sponge body (Webb et al. 2019). Secondary metabolites that chelate (i.e., bind) $\mathrm{Ca}^{2+}$ in exchange for $\mathrm{H}^{+}$have been suggested to contribute to this process (Sullivan and Faulkner 1990). We propose that $\mathrm{Ca}^{2+}$-ATPases on the excavating cell membrane can further accelerate the release of protons used for dissolution into the etching front (Fig. 4c), as seen in excavating cyanobacteria, but this remains to be tested (Garcia-Pichel et al. 2010; Guida and Garcia-Pichel 2016). 
Our study allows us to infer that dinoflagellate photosynthesis enhances sponge bioerosion due to provision of a high-caloric and, most importantly, a richly oxygenated microenvironment that secures the energetic potential needed to dissolve calcium carbonate in saturated seawater. As such, we highlight an often-neglected paradigm of ecosystem nestedness on coral reefs, where photosynthesis of endosymbiotic dinoflagellates promotes erosion of coral frameworks. More elaborate studies that synthesize physiological, biochemical, and mineralogical principles in the holobiont-including the physiological functions of the wide variety of other microbial symbionts of these sponges-are needed to better understand current and predict future biological erosion of already impacted coral reefs.

Acknowledgements We are grateful to Mark Vermeij, Kristen Marhaver and the CARMABI research station staff for their generous support, and to Benjamin Mueller and Andreas Haas for providing/ advising on parts of the experimental setup. Goby Divers Curaçao are thanked for helping with the oxygen setup. We thank NIOZ for the use of the automated spectrophotometric alkalinity system and for nutrient analyses. This project has received funding from the Ecology Fund of the Royal Netherlands Academy of Arts and Sciences (KNAW C2323.0290 to M. Achlatis) and the European Research Council under the European Union's Horizon 2020 research and innovation programme (ERC starting grant agreement $n^{\circ} 715513$ to J.M. de Goeij). The lead author is also grateful for the support of the Australian-American Association and the California Academy of Sciences during manuscript preparation. In addition, the lead author would like to thank Sophie Dove for early discussions that inspired this study. All research was conducted under the annual Curaçaoan Ministry of Health, Environment and Nature research permit (48584) issued to the CARMABI Foundation.

\section{Declarations}

Conflict of interest On behalf of all authors, the corresponding author states that there is no conflict of interest.

Open Access This article is licensed under a Creative Commons Attribution 4.0 International License, which permits use, sharing, adaptation, distribution and reproduction in any medium or format, as long as you give appropriate credit to the original author(s) and the source, provide a link to the Creative Commons licence, and indicate if changes were made. The images or other third party material in this article are included in the article's Creative Commons licence, unless indicated otherwise in a credit line to the material. If material is not included in the article's Creative Commons licence and your intended use is not permitted by statutory regulation or exceeds the permitted use, you will need to obtain permission directly from the copyright holder. To view a copy of this licence, visit http://creativecommons. org/licenses/by/4.0/.

\section{References}

Achlatis M, van der Zande RM, Schönberg CHL, Fang JKH, HoeghGuldberg O, Dove S (2017) Sponge bioerosion on changing reefs: ocean warming poses physiological constraints to the success of a photosymbiotic excavating sponge. Sci Rep 7:10705
Achlatis M, Schönberg CHL, van der Zande RM, Lajeunesse TC, Hoegh-Guldberg O, Dove S (2019) Photosynthesis by symbiotic sponges enhances their ability to erode calcium carbonate. J Exp Mar Bio Ecol 516:140-149

Achlatis M, Pernice M, Green K, Guagliardo P, Kilburn MR, HoeghGuldberg O, Dove S (2018) Single-cell measurement of ammonium and bicarbonate uptake within a photosymbiotic bioeroding sponge. ISME J 12:1308

Allemand D, Tambutté É, Zoccola D, Tambutté S (2011) Coral calcification, cells to reefs. In: Dubinsky Z, Stambler N (eds) Coral reefs: an ecosystem in transition. Springer, Dordrecht, pp 119-150

Arillo A, Bavestrello G, Burlando B, Sara M (1993) Metabolic integration between symbiotic cyanobacteria and sponges: a possible mechanism. Mar Bio 117:159-162

De Bakker DM, Webb AE, van den Bogaart LA, Van Heuven SMAC, Meesters EH, van Duyl FC (2018) Quantification of chemical and mechanical bioerosion rates of six Caribbean excavating sponge species found on the coral reefs of Curaçao. PLoS ONE 13:1-22

Berg JM, Tymoczko JL, Stryer L (2006) Biochemistry, 6th edn. W. H. Freeman and Company, New York

Ben-Amotz A, Sussman I, Avron M (1982) Glycerol production in Dunaliella. In: Mislin H, Bachofen R (eds) New trends in research and utilization of solar energy through biological systems. Springer, Basel, pp 55-59

Boury-Esnault N (1977) A cell type in sponge involved in the metabolism of glycogen: the gray cells. Cell Tissue Res 175:523-539

Breland JA, Byrne RH (1993) Spectrophotometric procedures for determination of sea water alkalinity using bromocresol green. Deep Sea Res Part I 40:629-641

Cantin NE, Negri AP, Willis BL (2007) Photoinhibition from chronic herbicide exposure reduces reproductive output of reef-building corals. Mar Ecol Prog Ser 344:81-93

Colombo-Pallotta MF, Rodríguez-Román A, Iglesias-Prieto R (2010) Calcification in bleached and unbleached Montastraea faveolata: evaluating the role of oxygen and glycerol. Coral Reefs 29:899-907

Crossland C, Barnes D, Borowitzka M (1980) Diurnal lipid and mucus production in the staghorn coral Acropora acuminata. Mar Biol 60:81-90

Davy SK, Allemand D, Weis VM (2012) Cell biology of cnidariandinoflagellate symbiosis. Microbiol Mol Biol Rev 76:229-261

Dittami SM, Arboleda E, Auguet J-C, Bigalke A, Briand E, Cárdenas P, Cardini U, Decelle J, Engelen AH, Eveillard D, Gachon CMM, Griffiths SM, Harder T, Kayal E, Kazamia E, Lallier FH, Medina M, Marzinelli EM, Morganti TM, Núñez Pons L, Prado S, Pintado J, Saha M, Selosse M-A, Skillings D, Stock W, Sunagawa S, Toulza E, Vorobev A, Leblanc C, Not F (2021) A community perspective on the concept of marine holobionts: current status, challenges, and future directions. PeerJ 9:e10911

Fang JKH, Schönberg CHL, Hoegh-Guldberg O, Dove S (2016) Daynight ecophysiology of the photosymbiotic bioeroding sponge Cliona orientalis Thiele, 1900. Mar Biol 163:1-12

Fang JKH, Schönberg CHL, Hoegh-Guldberg O, Dove S (2017) Symbiotic plasticity of Symbiodinium in a common excavating sponge. Mar Biol 164:1-11

Fang JKH, Schönberg CHL, Mello-Athayde MA, Hoegh-Guldberg O, Dove S (2014) Effects of ocean warming and acidification on the energy budget of an excavating sponge. Glob Chang Biol 20:1043-1054

Fisher R, O'Leary RA, Low-Choy S, Mengersen K, Knowlton N, Brainard RE, Caley MJ (2015) Species richness on coral reefs and the pursuit of convergent global estimates. Curr Biol 25:500-505 
Garcia-Pichel F (2006) Plausible mechanisms for the boring on carbonates by microbial phototrophs. Sediment Geol 185:205-213

Garcia-Pichel F, Ramirez-Reinat E, Gao QJ, Ramírez-Reinat E, Gao QJ (2010) Microbial excavation of solid carbonates powered by P-type ATPase-mediated transcellular $\mathrm{Ca}^{2+}$ ) transport. Proc Natl Acad Sci U S A 107:21749-21754

Gazeau F, Urbini L, Cox TE, Alliouane S, Gattuso JP (2015) Comparison of the alkalinity and calcium anomaly techniques to estimate rates of net calcification. Mar Ecol Prog Ser 527:1-12

Glynn PW (1997) Bioerosion and coral-reef growth: a dynamic balance. In: Birkeland C (ed) Life and death pf coral reefs. Chapmann and Hall, New York, pp 68-95

González-Rivero M, Yakob L, Mumby PJ (2011) The role of sponge competition on coral reef alternative steady states. Ecol Modell 222:1847-1853

Goreau TF, Goreau NI, Goreau TJ (1979) Corals and coral reefs. Sci Am 241:124-136

Granados C, Camargo C, Zea S, Sánchez JA (2008) Phylogenetic relationships among zooxanthellae (Symbiodinium) associated to excavating sponges (Cliona spp.) reveal an unexpected lineage in the Caribbean. Mol Phylogenet Evol 49:554-560

Grant AJ, Trautman DA, Menz I, Hinde R (2006) Separation of two cell signalling molecules from a symbiotic sponge that modify algal carbon metabolism. Biochem Biophys Res Commun 348:92-98

Guida BS, Garcia-Pichel F (2016) Extreme cellular adaptations and cell differentiation required by a cyanobacterium for carbonate excavation. Proc Natl Acad Sci 113:5712-5717

Haas AF, Knowles B, Lim YW, Somera TMD, Kelly LW, Hatay M, Rohwer F (2014) Unraveling the unseen players in the ocean-a field guide to water chemistry and marine microbiology. $\mathrm{J}$ Vis Exp 21:1-16

Hoffmann F, Røy H, Bayer K, Hentschel U, Pfannkuchen M, Brümmer F, De Beer D (2008) Oxygen dynamics and transport in the Mediterranean spongeAplysina aerophoba. Mar Biol 153:1257-1264

Holcomb M, Tambutté E, Allemand D, Tambutté S (2014) Light enhanced calcification in Stylophora pistillata: effects of glucose, glycerol and oxygen. PeerJ 2:e375

Hydes D, Aoyama M, Aminot A, Bakker K, Becker S, Coverly S, Daniel A, Dickson AG, Grosso O, Kerouel R, van Ooijen J, Sato K, Tanhua T, Woodward EMS, Zhang JZ (2010) Determination of dissolved nutrients $(\mathrm{N}, \mathrm{P}, \mathrm{Si})$ in seawater with high precision and inter-comparability using gas-segmented continuous flow analysers. In: Hood EM, Sabine CL, Sloyan BM (eds) The GOSHIP repeat hydrography manual: a collection of expert reports and guidelines, IOCCP report number 14, ICPO publication series number 134, UNESCO-IOC, Paris, France. http://www. go-ship.org/HydroMan.html

Kelly LW, Haas AF, Nelson CE (2018) Ecosystem microbiology of coral reefs: linking genomic, metabolomic, and biogeochemical dynamics from animal symbioses to reefscape processes. Microbiol Ecosyst 3:1-5

Kennedy EV, Perry CT, Halloran PR, Iglesias-Prieto R, Schönberg CHL, Wisshak M, Form AU, Carricart-Ganivet JP, Fine M, Eakin CM (2013) Avoiding coral reef functional collapse requires local and global action. Curr Biol 23:912-918

Krause GH, Weis E (1991) Chlorophyll fluorescence and photosynthesis: the basics. Annu Rev Plant Physiol Plant Mol Biol 42:313-349

Kühl M, Cohen Y, Dalsgaard T, Jergensen BB, Revsbech NP (1995) Microenvironment and photosynthesis of zooxanthellae in scleractinian corals studied with microsensors for $\mathrm{O}_{2}, \mathrm{pH}$ and light. Mar Ecol Prog Ser 117:159-172
Kyung SS, Fritz L (2002) Diel changes in pyrenoid and starch reserves in dinoflagellates. Phycologia 41:22-28

LaJeunesse TC, Parkinson JE, Gabrielson PW, Jeong HJ, Reimer JD, Voolstra CR, Santos SR (2018) Systematic revision of Symbiodiniaceae highlights the antiquity and diversity of coral endosymbionts. Curr Biol 28:1-11

Lavy A, Keren R, Yahel G, Ilan M (2016) Intermittent hypoxia and prolonged suboxia measured in situ in a marine sponge. Front Mar Sci 3:263

Leggat W, Hoegh-Guldberg O, Dove S, Yellowlees D (2007) Analysis of an EST library from the dinoflagellate (Symbiodinium sp.) symbiont of reef-building corals. J Phycol 43:1010-1021

Liu X, Byrne RH, Lindemuth M, Easley R, Mathis JT (2015) An automated procedure for laboratory and shipboard spectrophotometric measurements of seawater alkalinity: continuously monitored single-step acid additions. Mar Chem 174:141-146

Loh T-L, Pawlik JR (2014) Chemical defenses and resource trade-offs structure sponge communities on Caribbean coral reefs. Proc Natl Acad Sci 111:4151-4156

López-Victoria M, Zea S (2005) Current trends of space occupation by encrusting excavating sponges on Colombian coral reefs. Mar Ecol 26:33-41

McFall-Ngai M, Hadfield MG, Bosch TCG, Carey HV, DomazetLošo T, Douglas AE, Dubilier N, Eberl G, Fukami T, Gilbert SF, Hentschel U, King N, Kjelleberg S, Knoll AH, Kremer N, Mazmanian SK, Metcalf JL, Nealson K, Pierce NE, Rawls JF, Reid A, Ruby EG, Rumpho M, Sanders JG, Tautz D, Wernegreen JJ (2013) Animals in a bacterial world, a new imperative for the life sciences. Proc Natl Acad Sci U S A 110:3229-3236

Moberg F, Folke C (1999) Ecological goods and services of coral reef ecosystems. Ecol Econ 29:215-233

Müller WEG, Belikov SI, Kaluzhnaya OV, Chernogor L, Krasko A, Schröder HC (2009) Symbiotic interaction between dinoflagellates and the demosponge Lubomirskia baicalensis: aquaporinmediated glycerol transport. In: Mueller WEG, Grachev MA (eds) Biosilica in evolution, morphogenesis and nano-biotechnology. Springer, Heidelberg, pp 145-170

Nava H, Carballo JL (2008) Chemical and mechanical bioerosion of boring sponges from Mexican Pacific coral reefs. J Exp Biol 211:2827-2831

Negri A, Vollhardt C, Humphrey C, Heyward A, Jones R, Eaglesham G, Fabricius K (2005) Effects of the herbicide diuron on the early life history stages of coral. Mar Pollut Bull 51:370-383

Pineda M, Strehlow B, Sternel M, Duckworth A, Webster NS (2017) Effects of suspended sediments on the sponge holobiont with implications for dredging management. Sci Rep 7:4925

Pita L, Rix L, Slaby BM, Franke A, Hentschel U (2018) The sponge holobiont in a changing ocean: from microbes to ecosystems. BMC Microbiome 6:1-18

Pomponi SA (1979) Ultrastructure of cells associated with excavation of calcium carbonate substrates by boring sponges. J Mar Biol Assoc UK 59:777-784

Schindelin J, Arganda-Carreras I, Frise E, Kaynig V, Longair M, Pietzsch T, Preibisch S, Rueden C, Saalfeld S, Schmid B (2012) Fiji: an open-source platform for biological-image analysis. Nat Methods 9:676-682

Schönberg CHL (2008) A history of sponge erosion: from past myths and hypotheses to recent approaches. In: Wisshak M, Tapanila L (eds) Current developments in bioerosion. Springer, Berlin, pp 165-202

Schönberg CHL, Suwa R (2007) Why bioeroding sponges may be better hosts for symbiotic dinoflagellates than many corals. In: Porifera research: Biodiversity, innovation and sustainability (28th edn). Museu Nacional, Rio de Janeiro, Brazil 
Schönberg CHL, Fang JKH, Carballo JL (2017a) Bioeroding sponges and the future of coral reefs. In: Bell JJ, Carballo JL (eds) Climate change, ocean acidification and sponges. Springer, Berlin, pp 179-372

Schönberg CHL, Fang JKH, Carreiro-Silva M, Tribollet A, Wisshak M (2017b) Bioerosion: the other ocean acidification problem. ICES J Mar Sci 74:895-925

Shick JM (1990) Diffusion limitation and hyperoxic enhancement of oxygen consumption in zooxanthellate sea anemones, zoanthids, and corals. Biol Bull 179:148-158

Stanley GD (2006) Photosymbiosis and the evolution of modern coral reefs. Science 312:857-858

Strehlow BW, Jorgensen D, Webster NS, Pineda M-C, Duckworth A (2016) Using a thermistor flowmeter with attached video camera for monitoring sponge excurrent speed and oscular behaviour. PeerJ 4:e2761

Suescún-Bolívar LP, Iglesias-Prieto R, Thomé PE (2012) Induction of glycerol synthesis and release in cultured Symbiodinium. PLoS ONE 7:e47182

Sullivan BW, Faulkner DJ (1990) Chemical studies of the burrowing sponge Siphonodictyon coralliphagum. Proceedings of the 3rd international sponge conference, Woods Hole, USA

Underwood AJ (1997) Experiments in ecology, their logical design and interpretation using analysis of variance. Cambridge University Press, Cambridge

Venn AA, Loram JE, Douglas AE (2008) Photosynthetic symbioses in animals. J Exp Bot 59:1069-1080

Watanabe T, Yuyama I, Yasumura S (2006) Toxicological effects of biocides on symbiotic and aposymbiotic juveniles of the hermatypic coral Acropora tenuis. J Exp Mar Bio Ecol 339:177-188
Webb AE (2019) Reef dissolution: rates and mechanisms of coral dissolution by bioeroding sponges and reef communities. $\mathrm{PhD}$ Thesis, Utrecht University

Webb AE, Pomponi SA, van Duyl FC, Reichart GJ, de Nooijer LJ (2019) $\mathrm{pH}$ regulation and tissue coordination pathways promote calcium carbonate bioerosion by excavating sponges. Sci Rep 9:1-10

Webb AE, van Heuven SMAC, de Bakker DM, van Duyl FC, Reichart GJ, de Nooijer LJ (2017) Combined effects of experimental acidification and eutrophication on reef sponge bioerosion rates. Front Mar Sci 4:1-15

Weisz JB, Massaro AJ, Ramsby BD, Hill MS (2010) Zooxanthellar symbionts shape host sponge trophic status through translocation of carbon. Biol Bull 219:189-197

Wijgerde T, Jurriaans S, Hoofd M, Verreth JAJ, Osinga R (2012) Oxygen and heterotrophy affect calcification of the scleractinian coral Galaxea fascicularis. PLoS ONE 7:1-6

Wilkinson C (1979) Nutrient translocation from symbiotic cyanobacteria to coral reef sponges. In: Biologie des spongiaires, Colloques International du Centre National de la Recherche Scientifique, Paris, 291: 373-380

Yao W, Byrne RH (1998) Simplified seawater alkalinity analysis: use of linear array spectrometers. Deep Sea Res Part I 45:1383-1392

Zea S, Weil E (2003) Taxonomy of the Caribbean excavating sponge species complex Cliona caribbaea-C. aprica-C. langae (Porifera, Hadromerida, Clionaidae). Caribb J Sci 39:348-370

Zundelevich A, Lazar B, Ilan M (2007) Chemical versus mechanical bioerosion of coral reefs by boring sponges-lessons from Pione cf. vastifica. J Exp Biol 210:91-96

Publisher's Note Springer Nature remains neutral with regard to jurisdictional claims in published maps and institutional affiliations. 